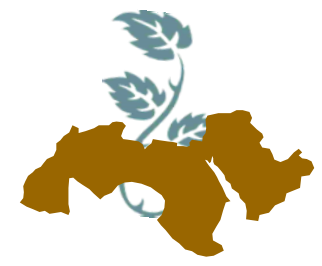

\title{
ENVIRONMENTAL IMPACT OF VETERINARY THERAPEUTIC AGENTS ON GROWTH AND BIOCHEMICAL COMPOSITION OF ERUCA SATIVA PLANT
}

Fatmalzhra, A. Awad'; R.K. Attallah" ${ }^{2}$; M.M. Shams Eldin ${ }^{2}$ and Shreen S. Ahmed ${ }^{1}$

1- Soil, Water and Environment Dept. Agric. Research Center (ARC), Giza, Egypt

2- Agric. Biochemistry Dept., Fac. of Agric., Ain Shams Univ., Cairo, Egypt

Keywords: Steroid hormones, Tetracycline antibiotics, Arugula (Eruca sativa), Chlorophyll, Proline, Antioxidant enzymes

\section{ABSTRACT}

Steroid hormones $(\mathrm{H})$ and tetracycline antibiotics ( $\mathrm{T}$ ) are considered two important classes of veterinary therapeutic agents administrated to livestock for different purposes that have been detected for many environmental matrices in wide concentrations range. The effect of progesterone (Pro), androstenedione (4-AD), androstadienedione $(1,4-A D)$ and tetracycline antibiotics namely oxytetracycline (OTC), chlortetracycline (CTC) and tetracycline (TC) on arugula plants (Eruca sativa) growth and biochemical composition was investigated. Compost and potassium permanganate were applied to minimizing the negative effect of veterinary therapeutic agents on plant. A pot experiment was conducted at the greenhouse of $\mathrm{Ag}$ ricultural Research Center (ARC) at Giza Governorate, Egypt. Soil fortified with $2 \mathrm{mg} \mathrm{kg}^{-1}$ of $\mathrm{H}$ and $\mathrm{T}$ target compounds individually and combined was used to study their effect on chlorophyll, proline, catalase (CAT), and peroxidase (POD) activities as antioxidant enzyme and plant growth. Under this experiment conditions; the obtained results showed that veterinary therapeutic agents caused increased the content of proline, however chlorophyll content was increased as a result of $\mathrm{H}$ application and decreased with T application. Both CAT and POD activities were increased, especially with the combined mixture application. Potassium permanganate or compost can be used for remediation procedures in veterinary therapeutic agents contaminated soils.

\section{INTRODUCTION}

Steroid hormones $(H)$ and antibiotics $(T)$ are considered two important classes of veterinary therapeutic agents administrated to livestock for many purposes that have been detected for many environmental matrices in wide range of concentrations.

Various plants have been found to uptake and accumulate these compounds. Lorenzen et al (2004) noticed that broiler litter contained approximately 55 and $30 \mathrm{mg} \mathrm{kg}^{-1}$ of estradiol and testosterone respectively, and breeder litter contained approximately 70 , and 23 to $30 \mathrm{mg} \mathrm{kg}^{-1}$ of both respectively. While androstenedione (4-AD) and progesterone (Pro) concentrations in fresh manure were below detection limit; surprisingly their concentrations in the surface soil reached $60 \mathrm{ng} \mathrm{g}^{-1}$ (Mansell et al 2011). Zheng et al 2007 noticed an increase in progesterone concentrations when dairy manure was aged, with concentrations increasing from below detection limits to about 200 ng g ${ }^{-1}$ over two weeks. Kumar et al (2005a) found that the levels of antibiotics in animal manures ranged from trace levels up to $200 \mathrm{mg} \mathrm{kg}^{-1}$. Administration of antibiotics via oral or intramuscular injection into the animals cannot be absorbed completely; therefore most of them which excreted with urine and feces as prototype or metabolites were calculated about $40-90 \%$ of the dose admitted. For example, the amount of chlortetracycline (CTC) at the treatment pool of pig's manure could be up to $1 \mathrm{mg} \mathrm{kg}^{-1}$ (Campagnolo et al 2002), whereas the amount of TC in liquid organic fertilizer could reach to $20 \mathrm{mg} \cdot \mathrm{kg}^{-1}$ (Hamscher et al 2002). Thus, when utilizing manures as organic fertilizers containing untreated antibiotics to agri- 
cultural soil, these antibiotics become the major sources of veterinary antibiotics in the soil environment. The widespread and global usage of steroids and antibiotics has made their occurrence present in the environment in natural and artificial systems. Soil, sediment, sludge, groundwater, wastewater, surface water, plants, and aquatic animals have been reported for contamination of steroid hormones and antibiotics (Matsui et al 2008). Kumar et al (2005b) determined three plants uptake, green onion, cabbage, corn from spiked soil with chlortetracycline (CTC), tylosin (TYL) and from fortified manure applied soils. Their data showed that plants take up just CTC in fresh green onion and cabbage. In another study, where the phytotoxic effect of tetracycline on Iberis sempervirens L., plants where antibiotic induced a large reduction in plant growth and development and inhibition of photosynthetic activity. As TC may cause oxidative stress in plants that try to balance this disequilibrium by scavenging ROS is generally via increasing the amount and activity of some endogenous enzyme antioxidant agents (SOD, CAT) and levels of antiradical secondary metabolites (Di Marco et al 2014). Genişel et al (2015) induced plant tolerance to lead toxicity $(1.75 \mathrm{mM})$ by treating wheat seeds with $\beta$-estradiol $(10 \mu \mathrm{M})$ either apart or combined, where $\beta$-estradiol reduced oxidative damage and improved the antioxidant system. While lead uptake was not prohibited by hormone addition, it stimulated the accumulation in plant roots.

The goal of this work was to investigate the effect for two types of veterinary pharmaceutical agents; steroid hormones and tetracycline antibiotics individually and combined on growth and chemical composition of arugula plant and to test natural and chemical oxidation approaches using compost and potassium permanganate to reduce plant uptake of target compounds thus reducing their adverse effects on plant tissues.

\section{MATERIALS AND METHODS}

A pot experiment was conducted at the greenhouse of ARC, Giza Governorate, Egypt. This study was carried out to test the effect of the selected steroidal hormones $(H)$ and antibiotics $(T)$ individually and combined (HT) on the biochemical composition of Eruca sativa plant, in addition to test natural and chemical oxidation approaches using compost at $5 \mathrm{~g} \mathrm{~kg}^{-1}$ and $\mathrm{KMnO}_{4}$ at $20 \mathrm{mg} \mathrm{kg}^{-1}$ to the soil to reduce plant uptake of target compounds thus reducing their adverse effects on plant tissues. The target compounds of steroidal hormones were Pro, 4-AD and 1,4-AD. The antibiotic target compounds were OTC, CTC and TC that added in a solution at $2 \mathrm{mg} \mathrm{kg}^{-1}$ to the soil after 4 days of germination. Seven arugula seeds were planted in each pot (10 cm diameter, $1 \mathrm{~kg}$ soil) with three replicates. Experiment was designed in complete randomize design. The sampling times were at 13,20 , and 27 days after germination.

Eight applications were used in three replicates as the following:

1. The soil solely as a control (C)

2. Soil $+\mathrm{KMnO}_{4}(\mathrm{O})$

3. Soil + target compounds ( $\mathrm{H}$ or $\mathrm{T}$ or $\mathrm{HT}$ )

4. Soil +target compounds $+\mathrm{KmnO}_{4}(\mathrm{H}$ or $\mathrm{T}$ or $\mathrm{HT}+\mathrm{O})$

5. Soil + compost (M)

6. Soil +compost $+\mathrm{KmnO}_{4}(\mathrm{M}+\mathrm{O})$

7. Soil +compost+ target compounds $(\mathrm{H}$ or $\mathrm{T}$ or $\mathrm{HT}+\mathrm{M}$ )

8. Soil +target compounds + compost+ $\mathrm{KmnO}_{4}(\mathrm{H}$ or $\mathrm{T}$ or $\mathrm{HT}+\mathrm{M}+\mathrm{O})$

\section{Determination of chlorophyll content}

Chlorophylls $a$ and $b$ were extracted from the sample in acetone. Their concentrations were determined spectrophotometrically by measuring the absorbance of the extract. The resulting absorbance measurements were then applied to a standard equation. Collected supernatants and were calorimetrically measured at $646 \mathrm{~nm}$ for chlorophyll a, and at $663 \mathrm{~nm}$ for chlorophyll b, to an UV-VIS spectrophotometer (Perkin Elmer Lambda 25). According to Lichtenthaler and Wellburn (1983) relationship equations chlorophyll content was measured as lanculov et al., 2005

$\mathrm{Chl} \mathrm{a}=12.21 .\left(\mathrm{A}_{663}\right)-2.81 .\left(\mathrm{A}_{646}\right)$,

Chl $b=20.13$. $\left(A_{646}\right)-5.03 .\left(A_{663}\right)$

\section{Determination of Proline}

Concentration of proline was calorimetrically measured using ninhydrin reagent according to Bates et al (1973). The frozen plant material was homogenized in $3 \%$ aqueous sulphosalicylic acid $(0.01 \mathrm{~g} / 0.5 \mathrm{ml})$. One $\mathrm{ml}$ of the homogenized tissue reacts with one $\mathrm{ml}$ acid-ninhdrin and one $\mathrm{ml}$ of glacial acetic acid in a test tube for one hour at $100^{\circ} \mathrm{C}$ and the reaction is terminated in an ice bath. The reaction mixture was extracted with $2 \mathrm{ml}$ toluene, mixed vigorously and left at room temperature for $30 \mathrm{~min}$ until separation of the two phases. The chromophore-containing toluene (1 $\mathrm{ml}$, upper 

composition of Eruca sativa plant

phase) was warmed to room temperature and its optical density was measured at $520 \mathrm{~nm}$ using toluene for a blank. The proline concentration was determined from a standard curve using D-Proline.

\section{Enzyme extraction}

For antioxidant enzyme assays, frozen leaves were ground to a fine powder with liquid nitrogen and were extracted with ice-cold $0.1 \mathrm{M}$ Tris- $\mathrm{HCl}$ buffer ( $\mathrm{pH} 7.5)$ containing $5 \%(\mathrm{w} / \mathrm{v})$ sucrose and $0.1 \% 2$-mercaptoethanol (3:1 buffer volume/FW). The homogenate was centrifuged at $10000 \mathrm{~g}$ for $20 \mathrm{~min}$, at $4^{\circ} \mathrm{C}$, and the supernatant was used for enzyme activity.

\section{Enzymes assay}

\section{A: Catalase determination}

CAT activity was determined by monitoring the disappearance of $\mathrm{H}_{2} \mathrm{O}_{2}$ at $240 \mathrm{~nm}\left(\varepsilon=40 \mathrm{mM}^{-1}\right.$ $\mathrm{cm}^{-1}$ ) according to the method of Aebi (1984). The reaction mixture contained $50 \mathrm{mM} \mathrm{K}$-phosphate buffer ( $\mathrm{pH}$ 7.0), $33 \mathrm{mM} \mathrm{H}_{2} \mathrm{O}_{2}$ and enzyme extract.

\section{B: Peroxidase determination}

POD activity was determined at $436 \mathrm{~nm}$ by its ability to convert guaiacol to tetraguaiacol $(\varepsilon=$ $26.6 \mathrm{mM}^{-1} \mathrm{~cm}^{-1}$ ) according to the method of Polle et al. (1994). The reaction mixture contained $100 \mathrm{mM}$ K-phosphate buffer $(\mathrm{pH} 7.0), 20.1 \mathrm{mM}$ guaiacol, $10 \mathrm{mM} \mathrm{H}_{2} \mathrm{O}_{2}$ and enzyme extract. The increase in absorbance was recorded by the addition of $\mathrm{H}_{2} \mathrm{O}_{2}$ at $436 \mathrm{~nm}$ for $5 \mathrm{~min}$.

\section{Statistical Analysis}

All data were statistically analyzed using Mstatc computer program according to procedures outlined by Freed and Scott, (1986).

\section{RESULTS AND DISCUSSION}

\section{Effect of pharmaceutical target compounds on chlorophyll content in plant}

Steroid hormones and tetracyclines individually and combined-treated plants grown in soil were analyzed to determine their content of chlorophyll. Fig. 1 shows the chlorophyll content in treated plant with steroid hormones (A), tetracyclines (B) and a mixture of both $(C)$. The highest chlorophyll values were recorded for $\mathrm{H}$ and $\mathrm{M}+\mathrm{H}$ treatments. In these treatments, chlorophyll reached 1.4- and 1.3-fold that of control, respectively. It was also found that the content of chlorophyll was insignificantly decreased as a result of applied $\mathrm{KMnO}_{4}$ compared without $\mathrm{KMnO}_{4}$ application. Chlorophyll content as a result of $\mathrm{H}+\mathrm{O}$ and $\mathrm{M}+\mathrm{H}+\mathrm{O}$ treatments reached 1.2-fold that of control.

Data of photosynthetic pigments showed that $\mathrm{H}$ application increased photosynthetic pigments and improved the ability of photosynthesis in plant. The present results were similar to that recorded for the increases of chlorophyll under steroidal hormone study by Czerpak and Szamrej (2003) where $\beta$ estradiol $10^{-6} \mathrm{M} \beta$-estradiol caused the strongest stimulatory effect on photosynthetic pigments in the range of $116-121 \%$ in comparison to the control treatment. On the other hand, concerning the effect of $T$ compounds significantly caused a reductionin chlorophyll content of plant leaves relatively to control. Decrease percent reached to $14 \%$, for $\mathrm{T}$ treatments. The present results are in agreement with that recorded for the decreases of chlorophyll under antibiotic stress as reported by Margas et al (2016). Michelini et al (2012) where a decrease in chlorophyll content induced by sulphadimetoxine antibiotic in Salix fragilis L. The data are in agreement with Di Marco et al 2014 that contributed the negative effect of tetracycline on chlorophyll due to an inhibition of enzyme activities involved in the synthesis of chlorophyll molecules. The effect of combined $\mathrm{T}$ and steroidal $\mathrm{H}$ on chlorophyll content of plant shows that the chlorophyll contents were increased. The highest values of chlorophyll contents were observed in HT and $\mathrm{M}+\mathrm{HT}$ treatments, however the lowest values recorded for the control treatment.

\section{Effect of pharmaceutical target compounds on proline content in plant}

Eruca sativa plants grown in fortified soil with steroid hormones and tetracyclines individually and combined were used to assess their content of proline. Fig.2 shows proline content in treated plant with steroid hormones $(A)$, tetracyclines $(B)$ and a mixture of both (C). Under this experiment conditions, $\mathrm{H}$ treatment resulted in a significant increment of proline content in plants in a comparison with the control treatment. The $\mathrm{KMnO}_{4}$ and $\mathrm{C}$ treatments values were close and were almost insignificant whether in absence or presence of compost. It is worth to mention that compost treatment affected the proline content negatively in 


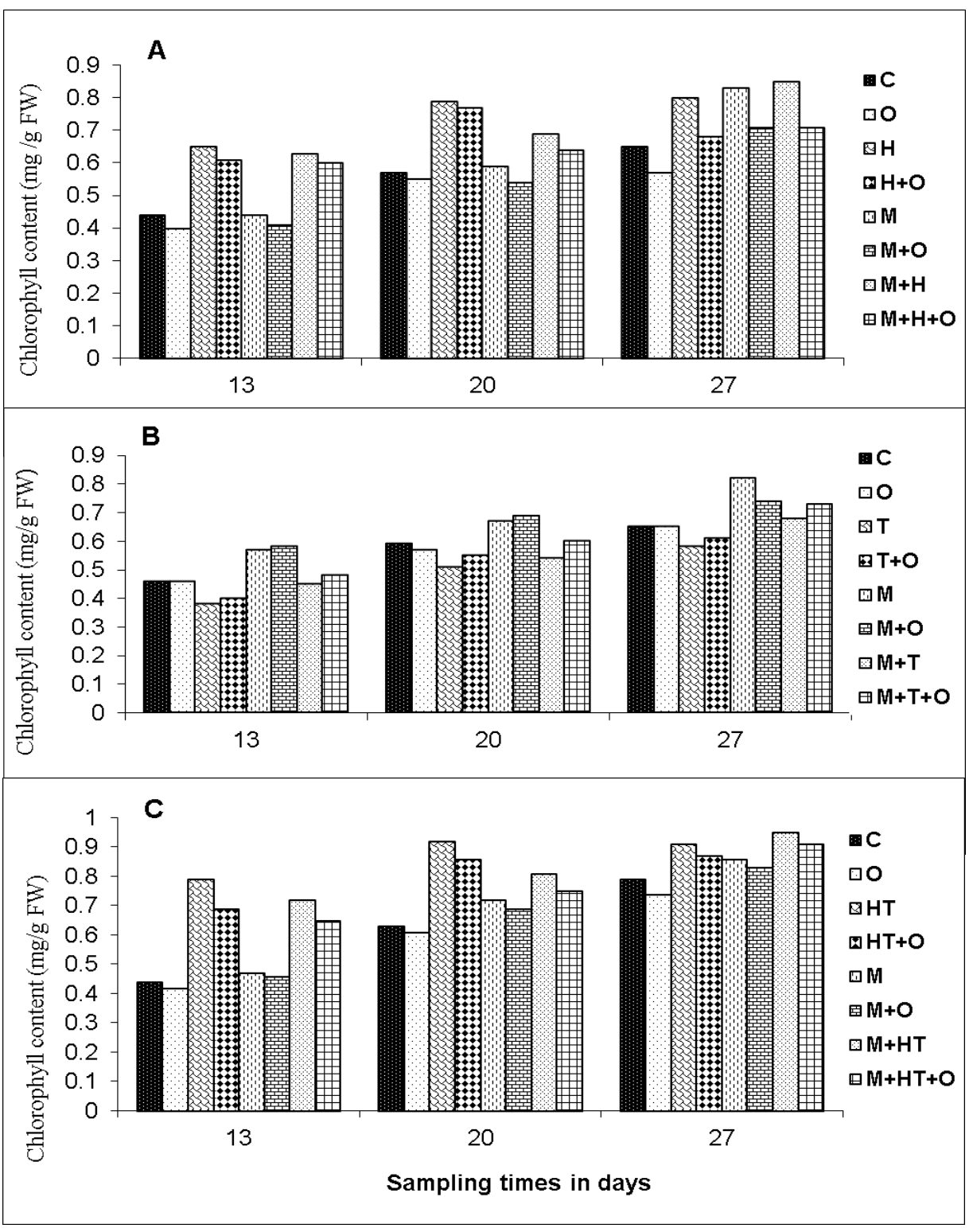

Fig. 1. Chlorophyll content in leaf extract of Eruca sativa grown in contaminated soil treated with hormones (A), tetracycline (B), and a mixture of both (C). 


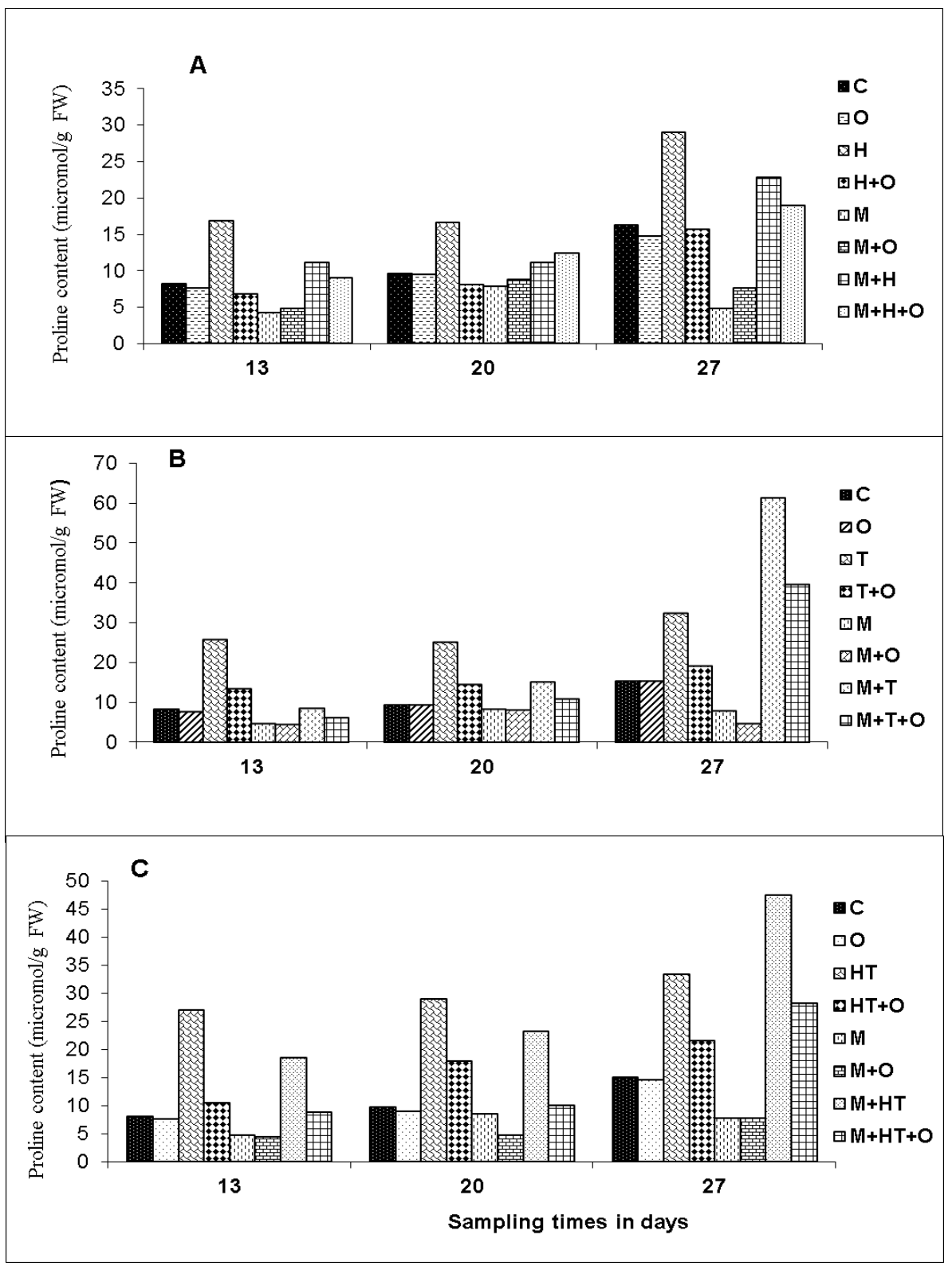

Fig. 2. Proline content in leaf extract of Eruca sativa grown in fortified soil treated with hormones $(\mathrm{A})$, tetracycline $(\mathrm{B})$, and a mixture of both $(\mathrm{C})$.

a significant way. The content of proline was in the following increasing order: $\mathrm{M}<\mathrm{M}+\mathrm{O}<\mathrm{O}$ and $\mathrm{H}+\mathrm{O}<$ $\mathrm{C}<\mathrm{M}+\mathrm{H}+\mathrm{O}<\mathrm{M}+\mathrm{H}<\mathrm{H}$. Data of the effect of tetracycline antibiotic on plants' proline content indicate a marked increment in proline content as a result of both of tetracycline antibiotic treatment $(T)$ and $M+T$ treatment compared with control. The significant increases in the proline contents, relative to control, were 2.5 and 2.6 -folds that of control for $\mathrm{T}$ and $\mathrm{M}+\mathrm{T}$ treatments, respectively.
Progressive decrements were observed in proline content as results of $\mathrm{M}+\mathrm{O}$ and $\mathrm{T}+\mathrm{M}+\mathrm{O}$ treatments application, where the decrease percentage in a comparison to the control reached to 47.7 and $37.6 \%$, respectively. Data of the effect of a mixture of both of $\mathrm{T}$ antibiotics and $\mathrm{T}$ on proline content of plant show a progressive increments in proline in plants that treated with a mixture of $\mathrm{T}$ antibiotic and $\mathrm{H}$, these significant increment induced by $\mathrm{HT}$ and $\mathrm{M}+\mathrm{HT}$ treatments reached up to 2.7 -fold that of 
control treatment. Generally, the contents of proline in plants of Eruca sativa were clearly affected by the pharmaceutical compounds applied. Proline can act as a source for cellular membrane osmotic adjustment. The obtained data are in agreement with that of Erdal (2012) who recorded that accumulation in proline in plant under estradiol application, also Sherafatmandjour et al (2013) found that estradiol at $10^{-9} \mathrm{M}$ positively affected fennel plant growth and development

\section{Effect of pharmaceutical target compounds on antioxidative enzyme activities in plants}

The obtained results from Eruca sativa plants grown in fortified soil with steroid hormones and tetracyclines individually and combined were used to evaluate their catalase (CAT) and peroxidase (POD) enzymes activities. Fig. 3 shows the CAT and POD enzymes activities in treated plant with steroid hormones $(A)$, tetracyclines $(B)$ and a mixture of both $(C)$ indicated that the CAT and POD activities were markedly increased in all different treatments (tetracycline or steroidal individually or combined) compared with control. Concerning the effect of selected steroidal hormone on antioxidative enzymes activities of Eruca sativa plants, the highest activity was observed in $\mathrm{M}+\mathrm{H}, \mathrm{H}, \mathrm{M}+\mathrm{H}+\mathrm{O}$, $\mathrm{M}+\mathrm{O}$ for CAT that reached 3.8, 2.7, 2.2, 2.2-folds compared to control. Regarding POD, the highest values were noticed for $\mathrm{H}$ and $\mathrm{H}+\mathrm{O}$ treatments that reached compared to control. Data reveal that the application of tetracycline, the highest significant values of CAT are recorded for $\mathrm{M}+\mathrm{T}, \mathrm{T}$ and $\mathrm{T}+\mathrm{O}$ treatments, however for POD they are recorded for $\mathrm{T}, \mathrm{T}+\mathrm{O}$. In general, plants treated with tetracycline had higher CAT and POD activities than that untreated plants, the increase in catalase activity was 3.5, 2.9 and 2.2-fold for $\mathrm{M}+\mathrm{T}, \mathrm{T}$ and $\mathrm{T}+\mathrm{O}$ treatments, respectively. The increase in peroxidase activity was 2.9, 1.6 and 1.2-fold for $\mathrm{T}, \mathrm{T}+\mathrm{O}$ and $\mathrm{M}+\mathrm{T}$ treatments respectively.

Significant effect of remediation approach by $\mathrm{KMnO}_{4}$ or compost application on catalase and peroxidase activities was observed. Regarding the effect of the combination of TC and steroidal hormone on anti-oxidative enzyme of Eruca sativa plants at different times, it is evident that both CAT and $P O D$ noticed in the following increasing magnitude: $\mathrm{M}+\mathrm{HT}>\mathrm{T}>\mathrm{T}+\mathrm{O}>\mathrm{M}+\mathrm{HT}+\mathrm{O}$. Significant effect of remediation by potassium permanganate or compost on CAT and POD was observed.
The present data are agreement with those obtained by Erdal and Dumlupinar (2010) who studied the effects of progesterone and $\beta$-estradiol on CAT and POD during germination and postgermination stages of chickpea seeds and noticed an increment in both CAT and POD activities.

\section{Effect of pharmaceutical compounds on growth of plant}

Fig. 4. Shows that Eruca sativa plants' growth influenced by steroid hormones $(A)$, tetracyclines (B) and a mixture of both (C). $\mathrm{H}$ treatment augmented the growth of Eruca Sativa plant compared to the control. The maximum growth was recorded as $55 \%, 40 \%$ and $32 \%$ for $\mathrm{H}, \mathrm{H}+\mathrm{O}$ and $\mathrm{M}+\mathrm{H}$ treatment compared to control. Our results are in agreement with Erdal (2012) that implied stimulating effects of human steroid hormone application on plants were due to increase in antioxidant activities in plant cells, which in turn enhance the plant resistance to environmental stresses. Yang et al (2005) characterized a putative Membrane Steroid Binding that binds progesterone with high affinity and functions in regulating growth in Arabidopsis. Estrogen binding proteins were reported in Solanaceae (Milanesi and Boland) and these steroid binding proteins specific for progesterone and $17 \beta$-estradiol were reported in Triticum aestivum (Janeczko et al 2008). Concerning the effect of tetracycline on plant growth, it diminished the growth of plants by $35 \%$ and $33 \%$, for $\mathrm{T}$ and $\mathrm{M}+\mathrm{T}$ treatments, respectively. There is insignificant difference between the other treatments. The phytotoxicity of an antibiotic to plants may be manifested by inhibition of germination and growth. These results are in agreement with Adomas et al 2013 who found that low doses of enrofloxacin inhibited lupin germination and elongation growth. Regarding combination of $\mathrm{H}$ and $\mathrm{T}$ treatment effect on plant growth. The highest growth was recorded at $\mathrm{HT}+\mathrm{O}, \mathrm{P}$ and $\mathrm{M}+\mathrm{HA}+\mathrm{O}$ treatments compared to control.

The obtained results showed that veterinary therapeutic agents stress caused typical biochemical changes in plants concerning the contents of chlorophyll, proline, and antioxidative enzyme activities. Potassium permanganate or compost can be used for remediation procedures in pharmaceutical compounds contaminated soils. Remediation by potassium permanganate or compost could be used as an in situ, in wide space area, and low cost. 


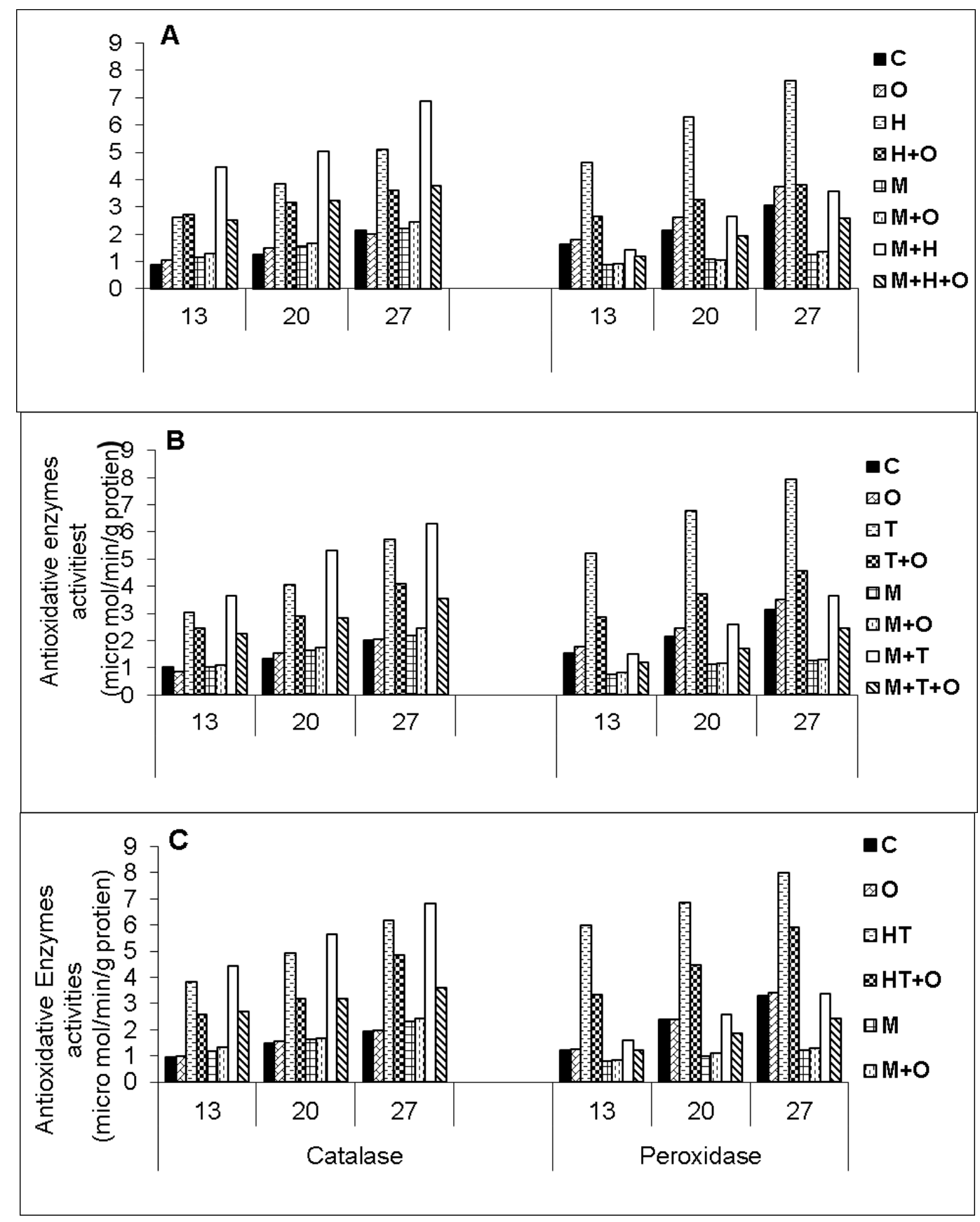

Fig. 3. Catalase and peroxidase enzymes activities in leaf extract of Eruca sativa grown in fortified soil treated with hormones $(A)$, tetracycline $(B)$, and a mixture of both $(C)$. 


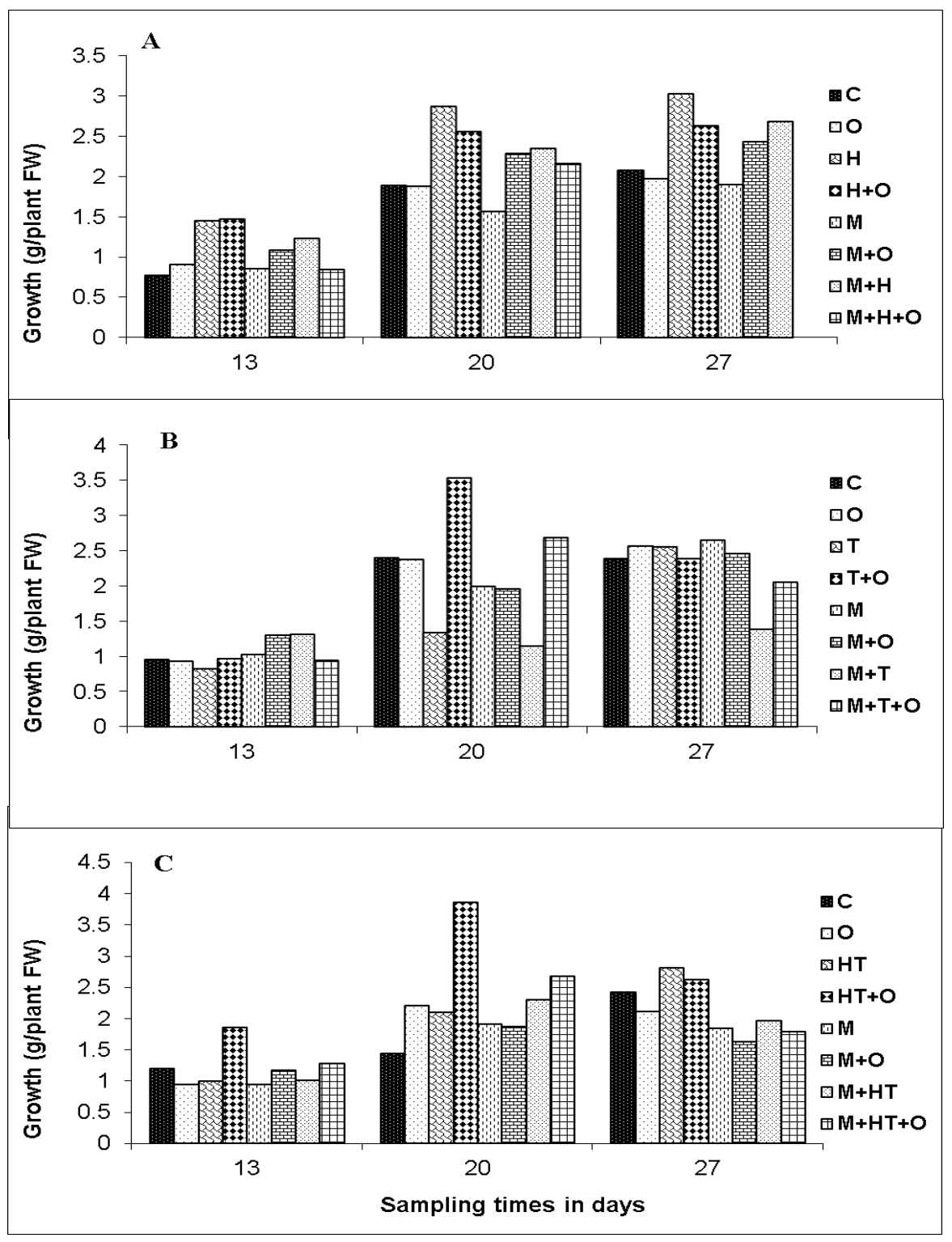

Fig. 4. Fresh weight of Eruca sativa grown in fortified soil treated with hormones (A), tetracycline (B), and a mixture of both (C)

\section{REFERENCES}

Adomas, B., Antczak-Marecka, J., NałęczJawecki G. and Piotrowicz-Cieślak, A.I. 2013. Phyotoxicity of enrofloxacin soil pollutant to narrow- leaved lupin plant. Polish Journal of Environmental Studies, 22, 71-76.

Aebi H. 1984. Catalase in vitro. Methods in Enzymology, 105, 121-126.
Bates, L.S., Waldren, R.P. and Teare I.D. 1973. Rapid determination of free proline for waterstress studies. Plant and Soil, 39(1), 205-207.

Campagnolo, E.R., Johnson, K.R., Karpati, A., Rubin, C.S., Kolpin, D.W., Meyer M.T., Esteban, J.E., Currier, R.W., Smith, K., Thu, K.M. and McGeehin, M., 2002. Antimicrobial residues in animal waste and water resources proximal to large-scale swine and poultry feeding operations. Sci. of the Total Environ., 299(1-3), 89-95. 

composition of Eruca sativa plant

Czerpak, R. and Szamrej, I.K. 2003. The Effect of $\beta$-estradiol and Corticosteroids on Chlorophylls and Carotenoids Content in Wolffia arrhiza (L.) Wimm.(Lemnaceae.) Wimm.(L.) Growing in Municipal Bialystok Tap Water. Polish J. of Environ. Studies, 12(6), 677-684.

Di Marco, G., Gismondi, A., Canuti, Scimeca L., M., Volpe, A. and Canini, A. 2014. Tetracycline accumulates in lberis sempervirens L. through apoplastic transport inducing oxidative stress and growth inhibition. Plant Biol., 16(4), 792-800.

Erdal, S. 2012. Exogenous mammalian sex hormones mitigate inhibition in growth by enhancing antioxidant activity and synthesis reactions in germinating maize seeds under salt stress. J. Sci. of Food and Agric., 92 (4), 839-843.

Erdal, S. and Dumlupinar, R. 2010. Progesterone and $\beta$-estradiol stimulate seed germination in chickpea by causing important changes in biochemical parameters. Zeitschrift für Naturforschung C, 65(3-4), 239-244.

Freed, R.D. and Scott, D.E. 1986. MSTATC. Crop and Soil Sci. Deptt., Michigan State University Michigan, USA

Genisel, M., Turk, H., Erdal, S., Demir, Y., Genc, E. and Terz,i I. 2015. Ameliorative role of betaestradiol against lead-induced oxidative stress and genotoxic damage in germinating wheat seedlings. Turkish J. of Botany, 39(6), 10521060

Hamscher, G., S. Sczesny, Höper, H. and Nau, H. 2002. Determination of persistent tetracycline residues in soil fertilized with liquid manure by high-performance liquid chromatography with electrospray ionization tandem mass spectrometry. Anal. Chem., 74(7),1509-1518

lanculov, I., Palicica, R., Butnariu, M., Dumbravă D. and Gergen, I. 2005. Obţinerea în stare cristalină a clorofilei din cetină de brad (Abies alba) şi de pin (Pinus sylvestris). Revista de chimie, 56(4), 441-443.

Janeczko, A., Budziszewska, B., Skoczowski, A. and Dybała, M. (2008). Specific binding sites for progesterone and $17 \beta$-Estradiol in cells of Triticum aestivum L. Acta Biochimica Polonica, 55 (4), 707-711.

Kumar, K., Gupta, S.C., Baidoo, S.K., Hander, Y.C. and Rosen, C.J. 2005b. Antibiotic uptake by plants from soil fertilized with animal manure. J. of Environ. Quality, 34(6), 2082-2085.

Kumar, K., Gupta, S.C., Chander, Y. and Singh, A.K. 2005a. Antibiotic use in agriculture and its impact on the terrestrial environment. Adv. in Agron., 87, 1-54.

Lichtenthaler H.K. and Wellburn, R.R. 1983. Determination of total carotenoids and chlorophyllls $a$ and $b$ of extracts in different solvents. Biochemical Society Transactions 603: 591592.

Lorenzen, A., Hendel, J.G. Conn, K.L., Bittman, Kwabiah, S.A.B., Lazarovitz, G., Masse D., McAllister, T.A. and Topp, E., 2004. Survey of hormone activities in municipal biosolids and animal manures. Environ. toxicology, 19(3), 216-225.

Mansell, D.S., Bryson, R.J., Harter, T., Webster, J.P., E.P. Kolodziej and Sedlak, D.L. 2011. Fate of endogenous steroid hormones in steer feedlots under simulated rainfall-induced runoff. Environ. Sci. and Tech., 45(20), 88118818.

Margas, M., Piotrowicz-Cieślak, A.l., Ziółkowska A. and Adomas, B. 2016. Tetracycline Accumulation in Pea Seedlings and its Effects on Proteome and Enzyme Activities. Int. J. of Agric. and Biol., 18(4),789-796.

Matsui, Y., Ozu, T., Inoue, T. and Matsushita, T., 2008. Occurrence of a veterinary antibiotic in streams in a small catchment area with livestock farms. Desalination, 226(1-3), 215-221.

Michelini, L., Meggio F., Rocca N.L., Ferro, S. and Ghisi, R. 2012. Accumulation and effects of sulfadimethoxine in Salix fragilis L. plants: a preliminary study to phytoremediation purposes. Int. J. of Phytoremediation, 14(4), 388402.

Polle, A., Otter, T. and Seifert, F. 1994. Apoplastic peroxidases and lignification in needles of Norway spruce (Picea abies L.). Plant Physiol., 106(1), 53-60.

Sherafatmandjour, A., Khorshidi, M. and Abavisani, A. 2013. Effect of estradiol on Photosynthetic pigments, proline and sugars in fennel. Int. J. of Farm. and Alli. Sci., 2(17), 567-57.

Yang, X.H., Xu Z.H. and Xue H.W. 2005. Arabidopsis membrane steroid binding protein 1 is involved in inhibition of cell elongation. The Plant Cell, 17(1), 116-131.

Zheng, W., Yates S.R. and Bradford S.A. 2007. Analysis of steroid hormones in a typical dairy waste disposal system. Environ. Sci. and Tech., 42(2), 530-535. 